\section{5. 膜型人工肺の試作}

東京父矤大 心臟血压研

$\begin{array}{ll}\text { 岸 三郎 } & \text { 佐藤 彰 } \\ \text { 太田 } \text { 諭 } & \text { 本多正知 } \\ \text { 森川哲夫 } & \text { 龍野勝彦 } \\ \text { 小柳 仁 } & \text { 今野草二 }\end{array}$

膜型人工肺が使用されるようになこてから，当研究 所での臨床例は 250 例をこし，その有用性が証明され てきている、しかしいまだ気泡型人工肺にとってかわ るほどまでに普及しえない理由は当研究所の場合

1. 酸素化能力に不安がある. (Landé-Edwards)

2. Set-up に時間を要与. 気泡型の場合(女子医大型) 15分程度であるが，膜型（Landé-Edwards）汇洗海

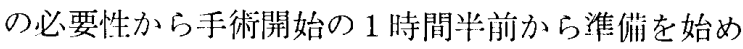
ている. Kolobow 型の場合は 1 時間ほど前に淮俑 を始妒チェックなどをする必要がある。

3. 抗抵圧が高く (Kolobow) 高流量時に危険を感し る。

などである。

昨年の人工臟器学会誌で岸は Polypropylene 膜を 用いた新しい人工肺を試作発表した.

今回発表する膜型人工肺の構造は前記の問題点をな るべく解決するようシンプルな構造とまた膜の特長を 生かすよう細部に改良を加えたもので，一応の成果を みたのでその構造, 膜の種類, 垁験方法, 成績などに ついて報告する。

構造 : 膜支持板の溝をダイヤモンドカットとし, 血 液方向を下から上への縦型をとり，これによ り dead space が少なくなった。

膜 : 各種の Polypropylene (Gelgard) の中でも $\mathrm{K}-72-6$ が $\mathrm{O}_{2}$ 值において良き成績を出した ので使用した。

実験方法: 模擬生体を作り各血流量抢上び酸素流量 との関係にて血液ガス值に变化を与をえた.

成績：血液ガス分析值中の $\mathrm{PO}_{2}$ 抢よび抵抗达など に打いて現在使用中の膜型人下肺と比較して 満足な成績を得たので報告する．

\section{1 回駆出量可変方式のローラ型血 液ポンプの開発の研究}

\author{
名古屋大 高気生治療部
}

榊原欣作高橋英世 小西信一郎 菅 原 修二

西山博司

名古屋大 第 1 外科

川村光生 小林繁夫 泉工医科工業

青木利三郎 若 井 秀 治 中山芳則

血液用のポンプとしてローラ型はさまざまの利点を 有し，今日ではほとんどまったく唯一の型式としてひ ろく全世界で使用されている．とくに通常のローラ型 は一種の定量ポンプとしての性質を有し，それが適正 に使用されるかぎり，ポンプ回転数をそのまま流量に 読替えできることも大きな特長の一つとされてきた. しかしその半面, ポンプ1回転による拍出量が一定で あるこの性質が，時にはかえって使用上の障害となる 場合もあり，またローラ型にこの特性があるために， さまざまの流量に適合できるよう，大小多種類の口径 のローラポンプが常備されなければならなかった.

この問題を解決するため，昨年，われわれは新しい 型式として, 単純な機構, 容易な操作などのローラ型 の他の特徵をそのまま活かしながら，1回駆出量を随 時, 自由に変化させることのできるローラポンプを開 発したことを報告した ${ }^{12}$.

この型式では従来のローラ型と異なり，ゴム管を挾 むローラの面およびポンプ外枠内面をポンプ軸に対し て傾斜させた形状とし，ゴム管のポンプヘッドに対寸 る相対的位置を移動させることによって，1回駆出量 をかなりの範囲に変化させようと試みた。試作の結果 はほぼ满足すべきであったが, 基本的な機構として, ポンプを回転させたままでゴム管を正確に，しかも一 操作てで移動させることは困難で，この点に実用上の問 題を残した.

この問題を改善するため，さらに多くの型式につい て検討した結果, 当初の試作で, ポンプ外枠内面を円 錐面とした点を改め，内涌を球面とすることによって ほぼ目的を達することができることを知った。

今回の報告では，この型式の詳細について報告する. 文 献

1）榊原欣作ほか：医器誌，45 (Suppl.) : 59, 1975. 